\title{
Article \\ Effect of Quercetin on Injury to Indomethacin-Treated Human Embryonic Kidney 293 Cells
}

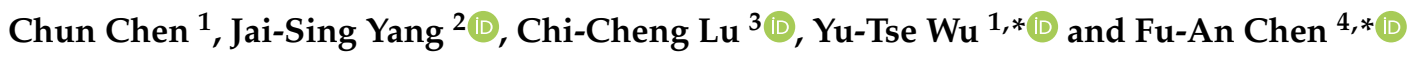 \\ 1 School of Pharmacy, College of Pharmacy, Kaohsiung Medical University, Kaohsiung City 807, Taiwan; \\ u106830006@kmu.edu.tw \\ 2 Department of Medical Research, China Medical University Hospital, China Medical University, \\ Taichung 404, Taiwan; jaisingyang@gmail.com \\ 3 Department of Sport Performance, National Taiwan University of Sport, Taichung 404, Taiwan; \\ a722353@ntupes.edu.tw \\ 4 Department of Pharmacy and Master Program, Tajen University, Pingtung 907, Taiwan \\ * Correspondence: ytwu@kmu.edu.tw (Y.-T.W.); fachen@tajen.edu.tw (F.-A.C.)
}

check for

updates

Citation: Chen, C.; Yang, J.-S.; Lu, C.-C.; Wu, Y.-T.; Chen, F.-A Effect of Quercetin on Injury to Indomethacin-Treated Human Embryonic Kidney 293 Cells. Life 2021, 11, 1134. https://doi.org/ $10.3390 /$ life11111134

Academic Editors:

Luiz Leonardo Saldanha and Thais Fernanda de Campos Fraga-Silva

Received: 13 September 2021

Accepted: 19 October 2021

Published: 25 October 2021

Publisher's Note: MDPI stays neutral with regard to jurisdictional claims in published maps and institutional affiliations.

Copyright: (c) 2021 by the authors. Licensee MDPI, Basel, Switzerland. This article is an open access article distributed under the terms and conditions of the Creative Commons Attribution (CC BY) license (https:// creativecommons.org/licenses/by/ $4.0 /)$.

\begin{abstract}
Nonsteroidal anti-inflammatory drugs (NSAIDs) are used to treat inflammation and pain and even to prevent the progression of cardiovascular disease. They have become widely used because of their effectiveness, especially among athletes performing high-intensity training. Indomethacin is used for pain management in sports medicine and is highly effective and versatile. However, several clinical studies have reported that indomethacin induces acute renal damage. In the present study, we determined that indomethacin reduced human embryonic kidney 293 (HEK293) cell viability in a concentration-dependent manner by triggering apoptosis. In addition, we demonstrated the effect of quercetin on indomethacin-treated HEK293 cells by inactivating the caspase-3 and caspase-9 signals. Furthermore, quercetin reduced ROS production and increased mitochondrial membrane potential $(\triangle \Psi \mathrm{m})$ in indomethacin-treated HEK293 cells. Our results indicate that quercetin can interrupt the activated caspase and mitochondrial pathway induced by indomethacin in HEK293 cells and affect apoptotic mRNA expression. Quercetin can protect against indomethacin-induced HEK293 cell apoptosis by regulating abnormal $\Delta \Psi \mathrm{m}$ and apoptotic mRNA expression.
\end{abstract}

Keywords: apoptosis; antioxidant; human embryonic kidney 293 (HEK293) cells; indomethacin; quercetin; mitochondrial membrane potential $(\Delta \Psi \mathrm{m})$

\section{Introduction}

Indomethacin, a nonsteroidal anti-inflammatory drug (NSAID), is a powerful prostaglandin synthesis inhibitor [1]. Its effectiveness has made it popular for pain relief [2,3] and for the prevention of pancreatitis after endoscopic retrograde cholangiopancreatography; indomethacin is also used for pain reduction in delayed-onset muscle soreness and for clinical treatment of rheumatoid arthritis [4-7]. However, researchers have reported adverse reactions to indomethacin, such as fluid retention, blood clots, myocardial infarction, hypertension, ulceration of the stomach or intestine, and impaired renal function [8-13].

Through regular, high-intensity training, athletes can easily experience sports injuries and are likely to use medications and supplements $[14,15]$. Athletes also usually experience muscle fatigue and fasciitis caused by long-term training. Furthermore, daily NSAID use is prevalent despite package inserts cautioning against chronic NSAID use $[16,17]$. No particular restrictions on nonsteroidal analgesics or anti-inflammatory drugs have been implemented. Therefore, painkillers and anti-inflammatory drugs are commonly used, and even abused, for treating sports injuries [18,19].

Excessive exercise increases myoglobin and creatine kinase, which can induce exerciseinduced rhabdomyolysis and even acute renal failure [20-22]. Indomethacin reduces blood flow to the kidneys; such reduced blood flow easily changes the permeability of 
the glomerular basement membrane and causes acute damage to the kidney [13]. During exercise, renal hemodynamics, including electrolyte and protein excretion, may cause renal blood flow to decrease to one-quarter of the normal level [23]. Because of the changes in renal function during exercise, indomethacin intake can compromise kidney function and increase acute renal failure incidence [13].

NSAIDs are commonly consumed as a fever reducers and analgesics, and because of their versatile effects, their daily use has become common [24]. Because athletes frequently experience physical stress and injuries, they might use painkillers to relieve discomfort [25]. Nevertheless, the adverse consequences and side effects of most of these drugs are underestimated [24,25]. NSAID intake can increase the chronic kidney disease (CKD) risk, and this risk may be greater than previously estimated. In a retrospective study of American military servicepeople, those using NSAIDs had $20 \%$ greater risks of acute kidney injury (AKI) and CKD [24]. However, although basic NSAIDs are versatile medications that are available over the counter (OTC), NSAIDs can induce adverse drug reactions that can result in hospitalization and death [26].

Flavonoids have been reported to be potential antioxidant chemopreventive agents [27-29]. In particular, quercetin has shown protective in vitro and in vivo abilities against chemically induced acute kidney damage by inducing antioxidant, inflammatory, and glomerular ultrastructural effects [30-34].

Indomethacin can reduce glomerular filtration and renal blood flow [13]. In the present study, we investigated the indomethacin-induced mitochondrial membrane potential $(\Delta \Psi \mathrm{m})$. Indomethacin-induced apoptosis involves the intrinsic apoptosis pathway and altered expression of caspase family proteins. To reduce or prevent adverse reactions and guide safe medication use in clinical settings, we investigated the pathway of indomethacin to understand how indomethacin induces kidney injury. In addition, we investigated quercetin as a potential preventive agent against indomethacin-induced kidney mitochondrial malfunction.

\section{Results}

2.1. Effect of Quercetin on Viability of Human Embryonic Kidney 293 Cells Treated with Indomethacin

Figure 1 presents the viability results for human embryonic kidney 293 (HEK293) cells after treatment with indomethacin at $0,125,250,500$, or $1000 \mu \mathrm{M}$. The viability of the HEK293 cells treated with indomethacin was significantly lower at higher indomethacin concentrations (Figure 1A).

We treated the HEK293 cells with 0, 25, 50, 75, or $100 \mu \mathrm{M}$ quercetin (Figure 1B). At 25,50 , and $75 \mu \mathrm{M}$, quercetin increased the viability of the HEK293 cells treated with indomethacin (Figure 1C). In particular, the cells treated with 50 and $75 \mu \mathrm{M}$ quercetin exhibited significant differences from the untreated cells. The trend in apoptotic cells was the reverse; quercetin treatment protected against apoptosis in indomethacin-treated cells in a concentration-dependent manner, as determined through transferase-mediated d-UTP nick end labeling (TUNEL) assay (Figure 1D, Table S1). Therefore, quercetin can protect against indomethacin-induced renal injury.

\subsection{Effect of Quercetin on Caspase-Dependent Apoptosis in HEK293 Cells Treated with Indomethacin}

To identify the intrinsic apoptosis pathway triggered by indomethacin in HEK293 cells, we measured the fold change in caspase levels versus the control cells. The addition of indomethacin significantly increased caspase-3 protein in HEK293 cells compared with the untreated cells (Figure 2A). Therefore, the caspase cascade pathway is associated with the mechanism through which indomethacin induces apoptosis in HEK293 cells. An increase in caspase-9 dependent on the indomethacin concentration occurred in the HEK293 cells, suggesting that indomethacin-induced apoptosis is related to increases in caspase3 and caspase-9 levels (Figure 2B). Quercetin at 50 and $75 \mu \mathrm{M}$ resulted in significantly lower caspase- 3 activity than was observed in the cells treated with indomethacin alone (Figure 2C). A similar trend in caspase-9 activity occurred (Figure 2D, Table S1). Therefore, 
quercetin treatment reduces the increased caspase- 3 and caspase- 9 activity in indomethacintreated HEK293 cells.

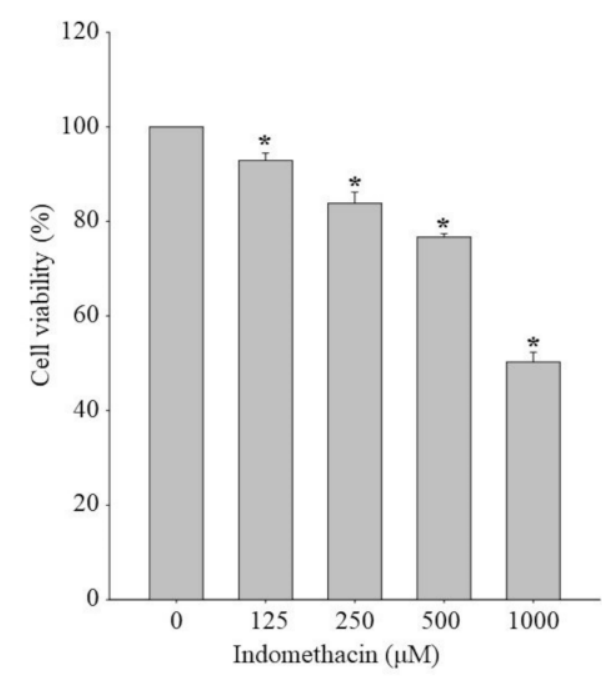

(A)

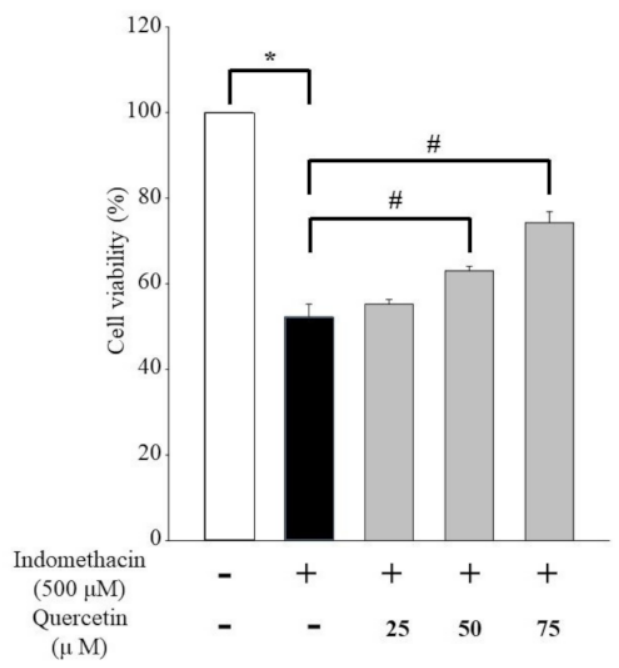

(C)

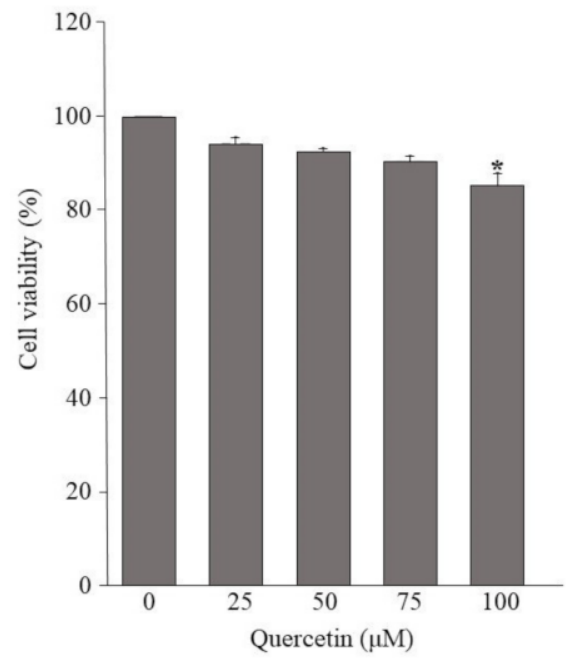

(B)

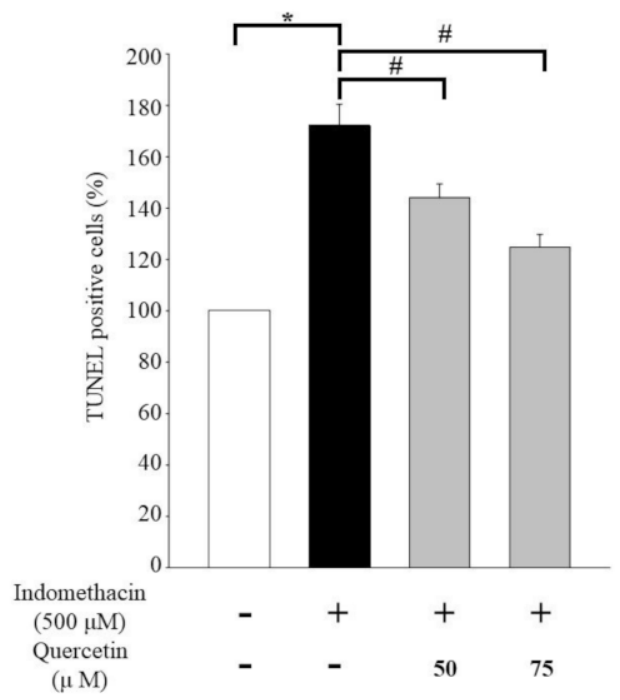

(D)

Figure 1. Viability of HEK293 cells treated with (A) indomethacin $(0,125,250,500$, or $1000 \mu \mathrm{M})$ or (B) quercetin $(0,25,50,75$, or $100 \mu \mathrm{M})$. (C) Viability of indomethacin-treated HEK293 cells exposed to 25,50 , or $75 \mu \mathrm{M}$ quercetin. (D) TUNEL-positive cells without quercetin or treated with 50 or $75 \mu \mathrm{M}$ quercetin and $500 \mu \mathrm{M}$ indomethacin were considered apoptotic. Values are expressed as means \pm standard errors $(\mathrm{n}=8)$. Dunnett's test was used to identify significant differences ${ }^{*} p<0.05$ vs. untreated cells; $\# p<0.05$ vs. cells with indomethacin treatment). 


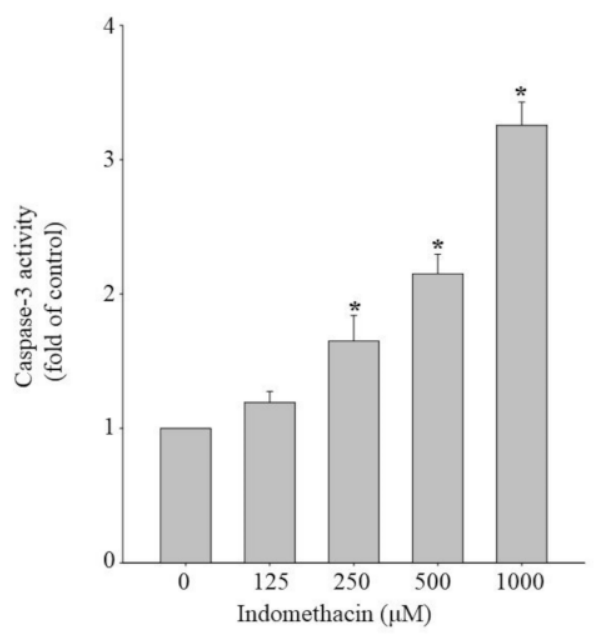

(A)

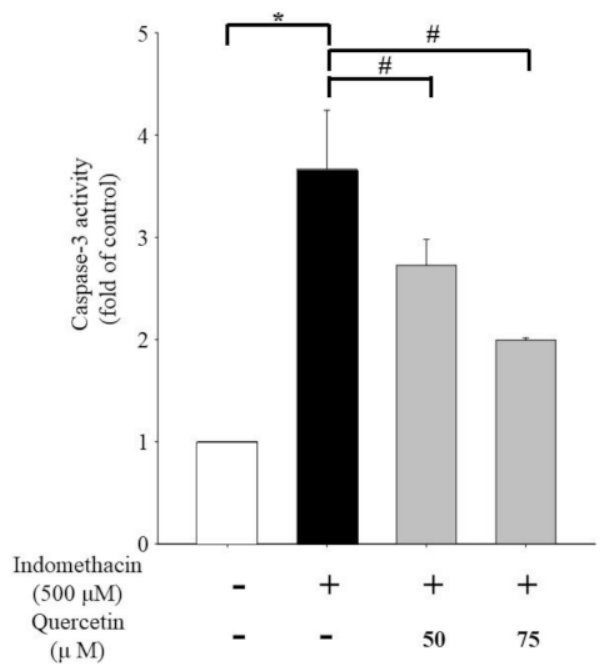

(C)

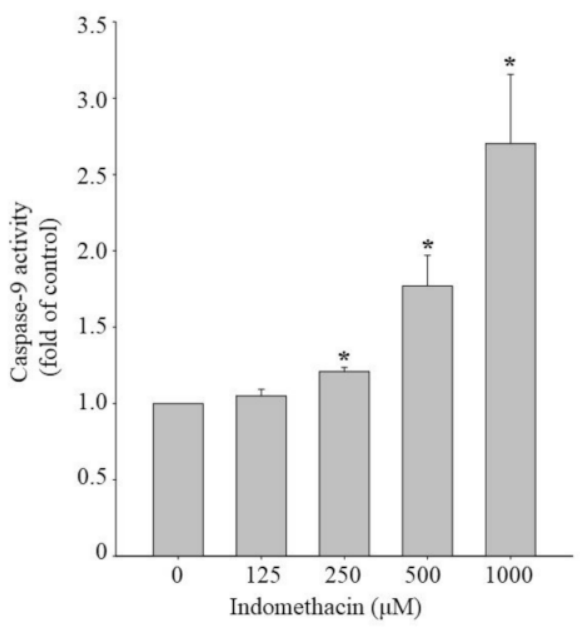

(B)

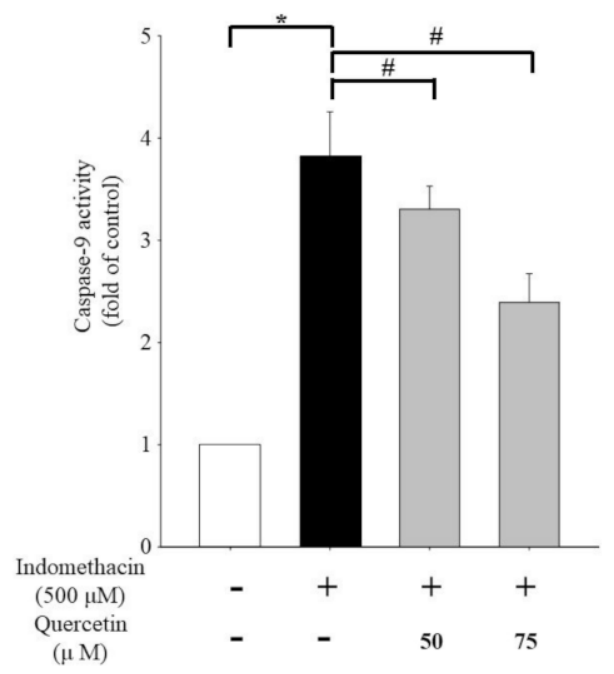

(D)

Figure 2. Effect of indomethacin on caspase activity in HEK293 cells. Fold changes in (A) caspase-3 and (B) caspase-9 activity in HEK293 cells after incubation with 125, 250, 500, or $1000 \mu \mathrm{M}$ indomethacin for $24 \mathrm{~h}$ (vs. $0 \mu \mathrm{M}$ ). (C) Caspase-3 and (D) caspase-9 activity in indomethacin-treated HEK293 cells in the presence of 50 or $75 \mu \mathrm{M}$ quercetin. Values are expressed as means \pm standard errors $(\mathrm{n}=8)$. Dunnett's test was used to determine significant differences $\left({ }^{*} p<0.05\right.$ vs. untreated cells; $\#$ p 0.05 vs. indomethacin treatment only).

\subsection{Effects of Quercetin on Superoxide Anion, Mitochondrial Superoxide, and Reactive Oxygen} Species Production in HEK293 Cells Treated with Indomethacin

We demonstrated that indomethacin-induced apoptosis involves an active caspase3/9-dependent pathway; in addition, quercetin can play a crucial role in suppressing caspase-dependent protein expression. To determine the effects of indomethacin and quercetin on upstream molecular signaling in HEK293 cells, we measured reactive oxygen species (ROS) production and mitochondrial membrane potential, as shown in Figure 3. To investigate indomethacin-induced apoptosis, a flow cytometric assay was used to determine $\triangle \Psi \mathrm{m}$, which was significantly lower in the HEK293 cells treated with higher concentrations of indomethacin $(p<0.05$; Figure $3 \mathrm{~A})$, indicating that indomethacin triggers mitochondrial malfunction. We also detected ROS production; in indomethacin-treated cells, the ROS level significantly increased; however, quercetin cotreatment resulted in significant decrease in the indomethacin-induced elevated ROS production (Figure 3B). 
Similar results were obtained for superoxide anion and mitochondrial superoxide levels (Figure 3C,D). Indomethacin significantly induced ROS production, explaining its ability to cause mitochondrial malfunction and subsequent apoptosis. In addition, quercetin exposure exerted an ostensible antioxidant effect on indomethacin-reduced peroxidation.

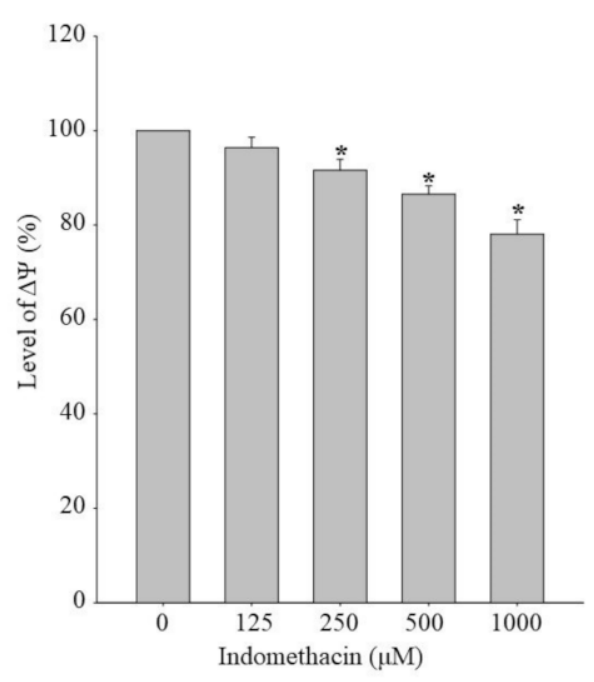

(A)

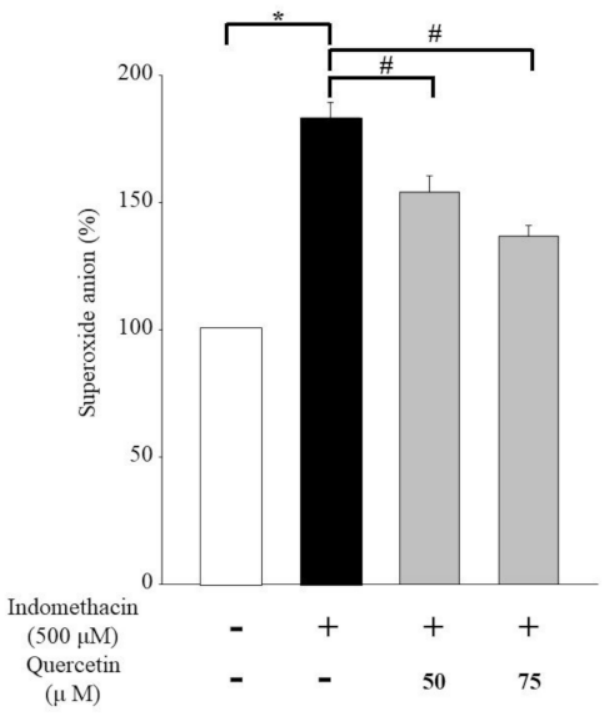

(C)

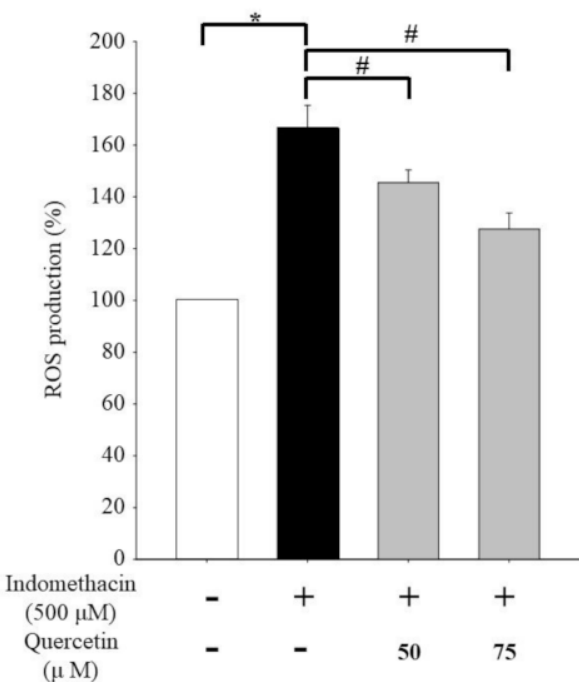

(B)

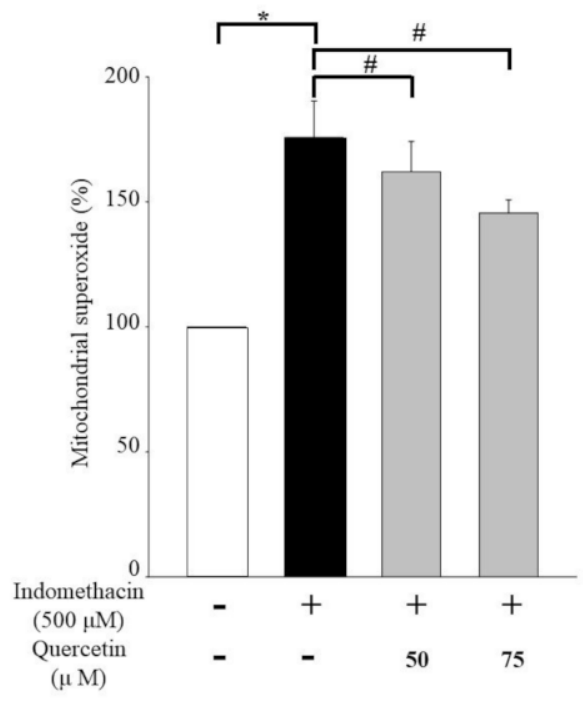

(D)

Figure 3. (A) Results for $\triangle \Psi \mathrm{m}$ in HEK293 cells incubated with indomethacin $(0,125,250,500$, or $1000 \mu \mathrm{M}$ ) for $24 \mathrm{~h}$. (B) ROS production results in HEK293 cells treated with $500 \mu \mathrm{M}$ indomethacin and 50 or $75 \mu \mathrm{M}$ quercetin. (C) Superoxide anion production results in HEK293 cells treated with 50 or $75 \mu \mathrm{M}$ quercetin and $500 \mu \mathrm{M}$ indomethacin. (D) Mitochondrial superoxide levels in HEK293 cells treated with 50 or $75 \mu \mathrm{M}$ quercetin and $500 \mu \mathrm{M}$ indomethacin. Indomethacin treatment was confirmed using DiOC6(3) fluorescent dye in flow cytometry analysis. ROS levels, superoxide anion production, and mitochondrial superoxide were respectively assessed using $\mathrm{H}_{2}$ DCFDA, dihydroethidium, and MitoSOX fluorescent dye staining in flow cytometry. Values are expressed as means \pm standard errors $(\mathrm{n}=8)$. Dunnett's test was used to determine significant differences $\left({ }^{*} p<0.05\right.$ vs. untreated cells; \# $p<0.05$ vs. indomethacin treatment only). 


\subsection{Effects of Pan-Caspase Inhibitor Z-VAD-FMK on Apoptosis in HEK293 Cells Treated} with Indomethacin

To show how protein expression regulates apoptosis in indomethacin-treated HEK293 cells, we used Z-VAD-FMK, which is a pan-caspase inhibitor, to block caspase-3 and caspase-9 activity. After exposure to Z-VAD-FMK, apoptosis in the indomethacin-treated and untreated HEK293 cells did not differ sionificantlv (Figure 4).

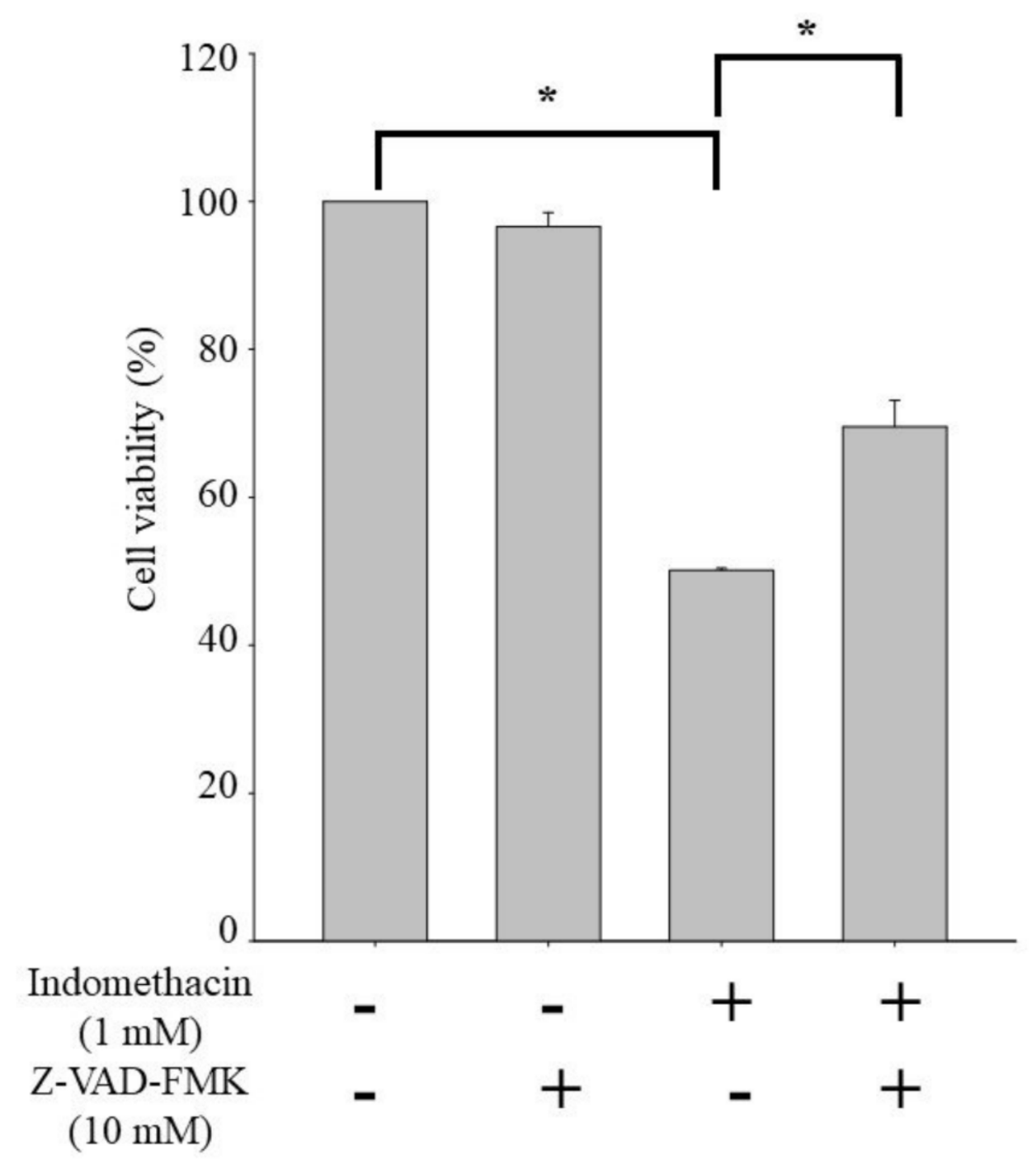

Figure 4. Apoptosis in indomethacin-treated HEK293 cells treated or untreated with the pancaspase inhibitor Z-VAD-FMK. Treated cells were exposed to $10 \mu \mathrm{M} Z$-VAD-FMK for $24 \mathrm{~h}$ before indomethacin treatment. Values are expressed as means \pm standard errors $(n=8)$. Dunnett's test was used to determine significant differences $\left({ }^{*} p<0.05\right.$ vs. untreated cells; ${ }^{*} p<0.05$ vs. indomethacin treatment only).

\subsection{Effects of Quercetin on Apoptotic mRNA Expression in HEK293 Cells Treated with Indomethacin}

To identify the caspase-dependent pathway and the effect of mRNA expression in indomethacin-treated HEK293 cells with or without quercetin cotreatment, we used caspase-3, caspase-9, AIF, and EndoG mRNA expression to represent mitochondrial function. We determined that quercetin has the potential to reduce apoptotic mRNA expression, including that of caspase-3, caspase-9, AIF, and EndoG (Figure 5). 


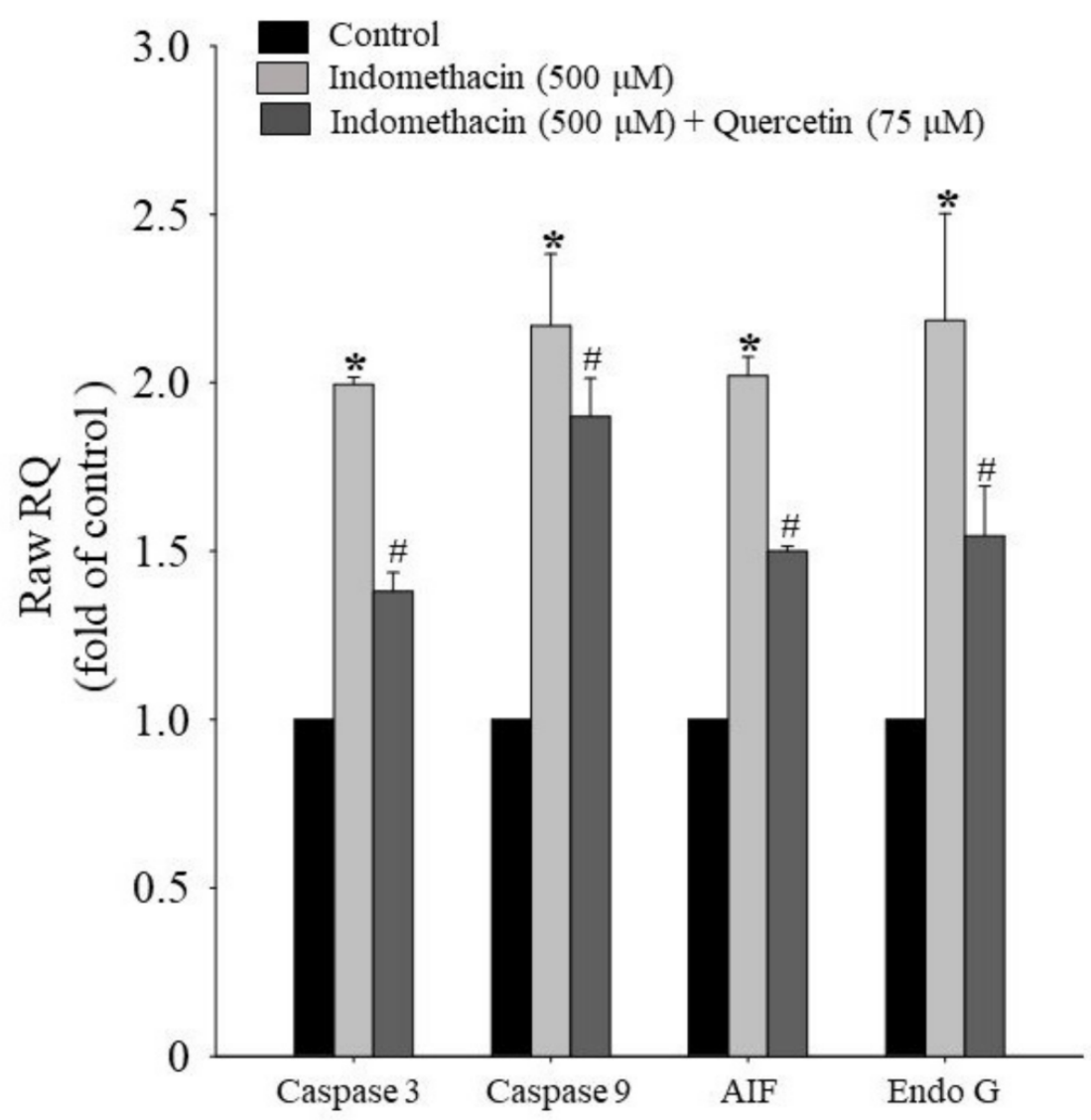

Figure 5. Effects of quercetin on apoptotic mRNA expression in HEK293 cells treated with indomethacin $(500 \mu \mathrm{M})$ and with or without quercetin $(75 \mu \mathrm{M})$ for $24 \mathrm{~h}$. Total mRNA was extracted to determine expression of caspase-3, caspase-9, AIF, and EndoG mRNA. Values are expressed as means \pm standard errors $(n=3)$. Dunnett's test was used to determine significant differences ( $p<0.05$ vs. untreated cells; \# $p<0.05$ vs. indomethacin treatment only).

\section{Discussion}

NSAIDs contribute to AKI by reducing renal blood flow, which induces renal tubule obstruction through crystal deposition; NSAIDs causes cytotoxicity to renal cells, cellmediated immune impairment, and acute interstitial nephritis [35]. CKD incidence was observed to be greater in patients who were administered NSAIDs [36]. In addition, although NSAIDs pose a risk of adverse drug reactions, they are still commonly used by patients with CKD [37]. Therefore, improving risk for patients with CKD is clinically desirable [26,38-40]. AKI is growing in global prevalence, resulting in significant substantial mortality and morbidity in which is requiring considerable medical resources. NSAIDs and various other nephrotoxic drugs are crucial causes of AKI, while exposure to such drugs is influenced by factors such as CKD status and age [41]. Older patients with renal disease are more likely than the general population to develop AKI from NSAID exposure; however, using evidence of the renal harm due to NSAIDs on complex interventions may be effective in reducing inappropriate NSAID prescriptions for high-risk populations [42,43]. Other studies have provided evidence for clinicians to use to minimize the risk of AKI when administering NSAIDs [26,41,44]. Approximately $13 \%$ to $18 \%$ of older adults and patients in hospitals develop end-stage renal disease; furthermore, older adults using NSAIDs at high doses have a $26 \%$ greater risk of acute renal failure. People with moderate to severe kidney disease who regularly use OTC NSAIDs typically also have NSAID prescriptions [36,45-47]. In clinical practice, commonly used NSAIDs such as aspirin and indomethacin can cause various forms of kidney damage, including acute 
interstitial nephritis, acute tubular necrosis, chronic renal tubular interstitial disease, renal tubular acidosis, and glomerular disease [23,48-52].

On the other hand, cyclooxygenase (COX) is the enzyme, involved in oxidizing arachidonic acid (AA), also known as the index of information and pain. COX contributes to inflammation processes in organs. The development, perfusion, water handling, and renin release in the kidney can be regulated by COX-2 in a normal or paraphysiological situation. Thus, patients are facing the risk of renal ischemia on NSAIDs, which reduce vasodilatory prostaglandins synthesis [53-55]. COX-2 plays a metabolites regulator in the kidney, in addition, NSAIDs long-term used could imbalance the renal homeostasis of COXs and bring the risk of renal injury [56,57].

Indomethacin induces renal epithelial cell injury by downregulating the Akt- and STAT3-related pathways [58,59]. In the present study, indomethacin upregulated caspase pathways. Specifically, indomethacin increased caspase-3 and -9 expression to induce apoptosis (Figure 2A,B and Figure 4). By contrast, cotreatment with quercetin resulted in significantly lower caspase-3/-9 activity in indomethacin-treated cells (Figure 2C,D). Mitochondria depend on the apoptosis pathway and caspase-3 and -9 for morphological changes, and ROS cleaving can indicate mitochondrial malfunction and result in insufficient energy reserves and intracellular signaling pathway activation $[60,61]$. In this study, we demonstrated the potential of quercetin to counteract indomethacin-induced caspase overexpression.

Long-term use of NSAIDs could cause a specific form of kidney disease which is characterized by papillary necrosis and interstitial scarring. COX2 inhibition may contribute to injury of the renal medulla [62]. In rat renal papilla cells, indomethacin $(1 \mu \mathrm{g} / \mathrm{mL})$ produced large inhibition of prostaglandin output from the renal papilla which provided the potential for renal injury [63]. Previous study has demonstrated indomethacin showed toxicity starting from concentrations of $10 \mu \mathrm{M}$ to $100 \mu \mathrm{M}$ in HEK293T cells in a dosedependent manner [64]. Indomethacin also provided the promotion of extracellular signalregulated kinase (ERK), p38 MAPK, and c-Jun N-terminal kinase (JNK) in 786-O renal cell carcinoma cells [59].

However, HEK293 cells have their own limitations on application. Researchers have discovered HEK293 cells have an unexpected relationship of neurons and begun to recognize which cannot be used as a normal model for renal function. In this study, we prefer to demonstrate the feasible potential of indomethacin and quercetin combo in cell lines. Accordingly, we selected HEK293 cells as an experimental model [65-67]. The toxicity of active drug components causes various types of kidney damage including cytotoxic damage to kidney mitochondrial and organelles; direct damage to the structure and function of mitochondria or mitochondrial death can lead to cell apoptosis. Mitochondrial apoptosis crucially regulates cell and death $[68,69]$. Indomethacin has been reported to instigate the endoplasmic reticulum (ER) stress response and $\mathrm{ER} \mathrm{Ca}^{2+}$ mobilization, both of which increase oxidative stress and induce mitochondrial dysfunction, regardless of oxygenation conditions [70-72]. We investigated the oxidation conditions and $\triangle \Psi \mathrm{m}$ in HEK293 cells. Indomethacin reduced $\Delta \Psi \mathrm{m}$ levels by inducing mitochondrial malfunction; conversely, with quercetin cotreatment, the level exhibited a significant reduction (Figure 3A). Mitochondrial membrane permeability is enhanced by the inhibition of ADP/ATP transportase in the mitochondrial membrane, causing mitochondrial disruption, or by the induction of calcium release in the ER and intracellular calcium flow, causing the ER stress reaction and activating phospholipase A2 for renal tubular epithelial cell apoptosis and toxicity [73]. Quercetin exposure ostensibly increased antioxidant activity in cells with indomethacinreduced peroxidation (Figure 3B-D). Quercetin can reduce oxidation levels in renal cells to inhibit the macrophage chemotaxis induced by ferroptosis in AKI and balance macrophage polarization $[74,75]$. Oxidative stress is a mechanism through which various drugs cause kidney damage. Quercetin can reverse $\Delta \Psi \mathrm{m}$ imbalance because of its antioxidant and free radical scavenging abilities $[27,76]$. In the clinic, the maximum daily recommended dose of indomethacin is $200 \mathrm{mg}$. The cell exposure in this study is higher than the situation of forecast from oral administration pharmacokinetics in the maximum daily dose 
(MDD) [77]. For studying the preventive effect of quercetin from indomethacin-induced injury we selected a higher concentration than the maximum daily dose. We demonstrated that quercetin has significant protection even in high concentration indomethacin treated $(500 \mu \mathrm{M})$ situation in HEK293 cells.

Mitochondria depend on apoptosis pathways that involve ROS production, DNA damage, $\Delta \Psi \mathrm{m}$ imbalance, and the release of the signal transporters Apaf-1, cytochrome c, procaspase-9, and AIF [78-80]. When ROSs induce DNA damage, the kinase that acts upstream of p53 autophosphorylation ataxia-telangiectasia mutates; after serial phosphorylation, downstream apoptotic factors such as Fas, CD95, DR4, DR5, and TNFR are expressed to induce apoptosis $[81,82]$. When ROS-induced DNA damage occurs, active autophagy in the cell continues, inducing the release of a DNase from mitochondria [83-86]. We demonstrated that with quercetin exposure, the level of apoptosis- and autophagy-related factors was lower in indomethacin-treated HEK-293 cells (Figure 5). AIF and EndoG are redox sensors in the metabolic pathways for apoptosis [83,87]. In the experiment, we found that quercetin had the potential to regulate ROS production and apoptosis- and autophagy-related factors.

The adverse consequences and side effects of NSAIDs are often underestimated [24,25]. They pose a high risk of AKI in people who use them without professional consultation, including athletes and older adults, as well as in long-term users $[15,16,26,88]$. In conclusion, indomethacin poses a substantial risk of renal damage; the present findings that indomethacin increased ROS production and $\Delta \Psi \mathrm{m}$ imbalance and upregulated caspase-3 and -9 as well as caspase-3/-9, AIF, and EndoG mRNA expression indicate that indomethacin induces renal injury. Knowledge of the risks of NSAID use can reduce the incidence of nephrotoxicity. Traditional and complementary medicine has grown in popularity because of its natural appeal and availability. Thus, research has targeted safe ingredients from Chinese medicine for use as complementary medicine to reduce the side effects of the pain and anti-inflammatory drugs taken by athletes, older adults, and patients on long-term pain medication $[29,89,90]$. Quercetin has therapeutic potential in cases of renal damage [91,92]. Previous studies have concluded that quercetin may effectively treat renal injury caused by chemical compounds that induce hypoxia [30,32,93,94]. In the present study, we used quercetin as a natural agent to reduce indomethacin-induced renal injury.

\section{Materials and Methods}

\subsection{Materials}

We obtained an In Situ Cell Death Detection Kit (Fluorescein), thiazolyl blue tetrazolium bromide (MTT), indomethacin, quercetin, Dulbecco's modified Eagle's medium (DMEM), DNase, and other reagents and chemicals from Sigma-Aldrich, Merck KGaA (Darmstadt, Germany). We obtained Muse Caspase-3/9 Assay Kits and the pan-caspase inhibitor Z-VADFMK from Millipore, Merck KGaA (Darmstadt, Germany). We obtained dihydroethidium, $2^{\prime}, 7^{\prime}$-dichlorodihydrofluorescein diacetate ( $\mathrm{H}_{2}$ DCFDA), 3,3'-dihexyloxacarbocyanine iodide [DiOC6(3)], and MitoSOX from Molecular Probes, Thermo Fisher Scientific (Waltham, MA, USA). We purchased L-glutamine, fetal bovine serum (FBS), trypsin-EDTA, and penicillin/streptomycin from HyClone, GE Healthcare Life Sciences (Logan, UT, USA).

\subsection{Cell Culture}

We purchased HEK293 cells from the American Type Culture Collection (Manassas, VA, USA). We cultured the cells in DMEM with 20\% FBS, 2 mM L-glutamine, and antibiotics (penicillin/streptomycin) in a $5 \% \mathrm{CO}_{2}$ humidified atmosphere at $37{ }^{\circ} \mathrm{C}$ until $100 \%$ confluence was reached; we replaced the medium every $48-72 \mathrm{~h}$. The cells were collected for cell viability testing; ROS, superoxide anion, and mitochondrial superoxide production assays; caspase- 3 and -9 assays, and TUNEL assay. 


\subsection{Cell Viability Assay}

The HEK293 cells $\left(2.5 \times 10^{4}\right.$ cells/well) were placed into 96-well plates with quercetin $(0,25,50,75$, or $100 \mu \mathrm{M})$ and subsequently exposed to indomethacin at concentrations of $125,250,500$, or $1000 \mu \mathrm{M}$ for $24 \mathrm{~h}$ to induce apoptosis before $1 \mathrm{~h}$ with or without treatment with $10 \mu \mathrm{M} \mathrm{Z-VAD-FMK}$; the cells were subsequently subjected to $2 \mathrm{~h}$ of treatment with $0.5 \mathrm{mg} / \mathrm{mL}$ MTT solution. Finally, $100 \mu \mathrm{L}$ of dimethyl sulfoxide was added to the wells to dissolve formazan crystals and replace the culture medium. The optical density was measured at $570 \mathrm{~nm}$ by using a spectrophotometer as previously described $[29,95]$.

\subsection{TUNEL Assay for Apoptosis Analysis}

With 50 or $75 \mu \mathrm{M}$ quercetin, $2.5 \times 10^{5}$ cells $/ \mathrm{mL}$ were plated into 24-well plates and treated with $500 \mu \mathrm{M}$ indomethacin for $24 \mathrm{~h}$. Before harvest, the cells were rinsed in phosphate-buffered saline. To detect apoptosis, flow cytometry was performed using a BD FACSCalibur Flow Cytometer (BD Biosciences, San Jose, CA, USA), and the In Situ Cell Death Detection Kit (Fluorescein; Sigma-Aldrich, Merck KGaA) was used in accordance with manufacturer instructions to stain the cells. BD Cell Quest Pro Software version 5.1 (BD Biosciences) was used in accordance with a previously described procedure [96] to quantify the cells testing positive in the TUNEL assay.

\subsection{Determination of Caspase-3 and -9 Activity}

Cells $\left(1 \times 10^{6}\right.$ cells $\left./ \mathrm{mL}\right)$ were cultured in a 10 -cm dish with 50 or $75 \mu \mathrm{M}$ quercetin and then treated with $500 \mu \mathrm{M}$ indomethacin for $24 \mathrm{~h}$ for the measurement of caspase protein expression. Before being harvested through centrifugation $(400 \times g$; Caspase- 3 and Caspase-9 Colorimetric Assay Kits, R\&D Systems Inc., Minneapolis, MN, USA), the cells were cultured in the working solution from the Muse Caspase-3/9 Assay Kits (Millipore; Merck KGaA) in accordance with manufacturer protocols [95,97].

\subsection{Determination of ROS and Mitochondrial Superoxide Production through Flow Cytometry}

HEK293 cells $\left(2.5 \times 10^{5}\right.$ cells $\left./ \mathrm{mL}\right)$ were cultured with 50 or $75 \mu \mathrm{M}$ quercetin and then treated with $500 \mu \mathrm{M}$ indomethacin for $24 \mathrm{~h}$. They were subsequently centrifuged for $5 \mathrm{~min}$ at $400 \times \mathrm{g}$. The cell pellets were harvested and suspended in a $500-\mu \mathrm{L}$ staining solution of $10 \mu \mathrm{M}$ H2DCF-DA, dihydroethidium, or MitoSOX for ROS, superoxide anion, or mitochondrial superoxide detection, respectively, and subsequently incubated for $30 \mathrm{~min}$ at $37^{\circ} \mathrm{C}$. ROS, superoxide anion, and mitochondrial superoxide production was detected as previously described through flow cytometry $[98,99]$.

\subsection{Detection of $\Delta \Psi m$}

HEK293 cells $\left(2.5 \times 10^{5}\right.$ cells $\left./ \mathrm{mL}\right)$ were cultured with 50 or $75 \mu \mathrm{M}$ quercetin and then treated with $500 \mu \mathrm{M}$ indomethacin for $24 \mathrm{~h}$. The cells were subsequently collected and labeled for $30 \mathrm{~min}$ at $37^{\circ} \mathrm{C}$ with $500 \mathrm{nM}$ DiOC6(3). Flow cytometry was used to analyze the fluorescence intensity corresponding to $\Delta \Psi \mathrm{m}$ in accordance with previously described methods $[96,100,101]$.

\subsection{Apoptotic mRNA Level Analysis}

Cells $\left(1 \times 10^{6}\right.$ cells/total $)$ were exposed for $24 \mathrm{~h}$ to $500 \mu \mathrm{M}$ indomethacin with or without $75 \mu \mathrm{M}$ quercetin. The assay proceeded in accordance with the protocol of the Qiagen RNeasy Mini Kit as described previously [102]. RNA samples were processed with kit reagent in accordance with the manufacturer's protocol (Applied Biosystems, Foster City, CA, USA) for $30 \mathrm{~min}$ at $42{ }^{\circ} \mathrm{C}$. The following protocol was used in the subsequent quantitative polymerase chain reaction: $2 \mathrm{~min}$ at $50^{\circ} \mathrm{C}, 10 \mathrm{~min}$ at $95^{\circ} \mathrm{C}, 40$ cycles of $15 \mathrm{~s}$ each at $95{ }^{\circ} \mathrm{C}$, and $1 \mathrm{~min}$ at $60^{\circ} \mathrm{C}$ with $1 \mu \mathrm{L}$ of complementary DNA that was reversetranscribed as described previously, 2X SYBR Green PCR Master Mix (Applied Biosystems), and the forward and reverse primers (200 nM; Table 1). All assays were performed three times on an Applied Biosystems 7300 Real-Time PCR System, and the comparative CT method was used to calculate the fold changes in mRNA level. 
Table 1. Primers used for apoptotic mRNA level analysis.

\begin{tabular}{cc}
\hline Primers & Sequences \\
\hline \multirow{2}{*}{ homo caspase-3 } & $5^{\prime}$-CAGTGGAGGCCGACTTCTTG-3' \\
& $3^{\prime}$-TGGCACAAAGCGACTGGAT-5 \\
homo caspase-9 & $5^{\prime}$-TGTCCTACTCTACTTCCCAGGTTTT-3' $^{\prime}$ \\
& $3^{\prime}$-GTGAGCCCACTGCTCAAAGAT-5' \\
homo AIF & $5^{\prime}$-GGGAGGACTACGGCAAAGGT-3' \\
& $3^{\prime}$-CTTCCTTGCTATTGGCATTCG-5 \\
homo Endo G & $5^{\prime}$-GTACCAGGTCATCGGCAAGAA-3 \\
& $3^{\prime}$-CGTAGGTGCGGAGCTCAATT-5' \\
\hline
\end{tabular}

\title{
4.9. Statistical Analysis
}

Dunnett's test and one-way analysis of variance were performed in SPSS version 16.0 (SPSS, Chicago, IL, USA). All values are the means \pm standard errors of the triplicate assays. A $p$ of $<0.05$ was considered to indicate statistical significance.

\section{Conclusions}

NSAID abuse is prevalent among athletes. The present study demonstrated that indomethacin reduces mitochondrial malfunction in HEK293 cells by affecting ROS production and $\Delta \Psi \mathrm{m}$ imbalance. NSAIDs have adverse effects on the kidneys. Because no restrictions have been enacted on nonsteroidal analgesics or anti-inflammatory drugs in athletes, athletes are susceptible to NSAID abuse. Herein, we report the risk of indomethacininduced renal malfunction; the results can provide professionals with insight for medication prescription among athletes. In addition, we identified quercetin as a natural reagent that can prevent mitochondrial malfunction and even apoptosis in indomethacin-treated HEK293 cells. The results suggest that combined quercetin and indomethacin therapy is feasible.

Supplementary Materials: The following are available online at https:/ /www.mdpi.com/article/10 $.3390 /$ life11111134/s1, Table S1: Supplement raw data.

Author Contributions: Conceptualization, C.C., J.-S.Y., C.-C.L. and F.-A.C.; methodology, C.C., J.-S.Y., C.-C.L. and F.-A.C.; validation, C.C., J.-S.Y., C.-C.L., Y.-T.W. and F.-A.C.; investigation, C.C., J.-S.Y., C.-C.L., Y.-T.W. and F.-A.C.; project administration, Y.-T.W. and F.-A.C.; visualization, C.C., J.-S.Y., C.-C.L., Y.-T.W. and F.-A.C.; supervision, J.-S.Y., Y.-T.W. and F.-A.C.; data curation, C.C., J.-S.Y. and F.-A.C.; writing - original draft preparation, C.C., J.-S.Y. and C.-C.L.; writing—review and editing, C.C., J.-S.Y., Y.-T.W. and F.-A.C.; funding acquisition, Y.-T.W. and F.-A.C. All authors have read and agreed to the published version of the manuscript.

Funding: This study was partially funded by the Ministry of Science and Technology of Taiwan, R.O.C. (Grant number MOST 108-2410-H-127-001-MY2, MOST 110-2410-H-127-001, MOST 109-2410H-037-018 and MOST 110-2410-H-037-008-MY2).

Acknowledgments: The authors thank the Ministry of Science and Technology for the financial support.

Conflicts of Interest: The authors declare no conflict of interest.

\author{
Abbreviations \\ ROS Reactive oxygen species \\ Apaf-1 Apoptotic protease activating factor-1 \\ AIF Apoptosis-Inducing Factor \\ Fas Fas ligand \\ CD95 Receptor CD95 \\ DR4 Death receptor 4 \\ DR5 Death receptor 5 \\ TNFR TNF-receptor \\ EndoG Endonuclease G \\ EDTA Ethylenediaminetetraacetic acid
}




\section{References}

1. Orczyk, G.P.; Behrman, H.R. Ovulation blockade by aspirin or indomethacin-In vivo evidence for a role of prostaglandin in gonadotrophin secretion. Prostaglandins 1972, 1, 3-20. [CrossRef]

2. Inamdar, S.; Han, D.; Passi, M.; Sejpal, D.V.; Trindade, A.J. Rectal indomethacin is protective against post-ERCP pancreatitis in high-risk patients but not average-risk patients: A systematic review and meta-analysis. Gastrointest. Endosc. 2017, 85, 67-75. [CrossRef] [PubMed]

3. Bucolo, C.; Melilli, B.; Piazza, C.; Zurria, M.; Drago, F. Ocular Pharmacokinetics Profile of Different Indomethacin Topical Formulations. J. Ocul. Pharmacol. Ther. 2011, 27, 571-576. [CrossRef]

4. Elmunzer, B.J.; Hernandez, I.; Gellad, W.F. The Skyrocketing Cost of Rectal Indomethacin. JAMA Intern. Med. 2020, 180, 631. [CrossRef] [PubMed]

5. Itoh, K.; Ochi, H.; Kitakoji, H. Effects of tender point acupuncture on delayed onset muscle soreness (DOMS)—A pragmatic trial. Chin. Med. 2008, 3, 14. [CrossRef] [PubMed]

6. Itoh, K.; Kawakita, K. Effect of Indomethacin on the Development of Eccentric Exercise-Induced Localized Sensitive Region in the Fascia of the Rabbit. Jpn. J. Physiol. 2002, 52, 173-180. [CrossRef] [PubMed]

7. Helleberg, L. Clinical Pharmacokinetics of Indomethacin. Clin. Pharmacokinet. 1981, 6, 245-258. [CrossRef] [PubMed]

8. Lago, P.; Bettiol, T.; Salvadori, S.; Pitassi, I.; Vianello, A.; Chiandetti, L.; Saia, O.S. Safety and efficacy of ibuprofen versus indomethacin in preterm infants treated for patent ductus arteriosus: A randomised controlled trial. Eur. J. Pediatr. 2002, 161, 202-207. [CrossRef]

9. Hilton, J.E.; Summers, M. The effect of polyvinylpyrrolidones on intestinal ulceration caused by indomethacin. Int. J. Pharm. 1986, 32, 13-19. [CrossRef]

10. Langenbach, R.; Morham, S.G.; Tiano, H.F.; Loftin, C.D.; Ghanayem, B.I.; Chulada, P.C.; Mahler, J.F.; Lee, C.A.; Goulding, E.H.; Kluckman, K.D.; et al. Prostaglandin synthase 1 gene disruption in mice reduces arachidonic acid-induced inflammation and indomethacin-induced gastric ulceration. Cell 1995, 83, 483-492. [CrossRef]

11. Pickard, J.; Tamura, A.; Stewart, M.; McGeorge, A.; Fitch, W. Prostacyclin, indomethacin and the cerebral circulation. Brain Res. 1980, 197, 425-431. [CrossRef]

12. Gary, N.E.; Dodelson, R.; Eisinger, R.P. Indomethacin-associated acute renal failure. Am. J. Med. 1980, 69, 135-136. [CrossRef]

13. Walker, R.J.; Fawcett, J.P.; Flannery, E.M.; Gerrard, D.F. Indomethacin potentiates exercise-induced reduction in renal hemodynamics in athletes. Med. Sci. Sports Exerc. 1994, 26, 1302-1306. [CrossRef]

14. Warner, D.C.; Schnepf, G.; Barrett, M.S.; Dian, D.; Swigonski, N.L. Prevalence, attitudes, and behaviors related to the use of nonsteroidal anti-inflammatory drugs (NSAIDs) in student athletes. J. Adolesc. Health 2002, 30, 150-153. [CrossRef]

15. Ciocca, M. Medication and Supplement Use by Athletes. Clin. Sports Med. 2005, 24, 719-738. [CrossRef]

16. Davis, B.R. Non-Steroidal Anti-Inflammatory Drug Use in Collegiate Athletes. Master's Thesis, Portland State University, Portland, OR, USA, 2015.

17. O'Connor, S.; McCaffrey, N.; Whyte, E.; Moran, K.; Lacey, P. Nonsteroidal anti-inflammatory drug use, knowledge, and behaviors around their use and misuse in Irish collegiate student-athletes. Physician Sportsmed. 2019, 47, 318-322. [CrossRef]

18. Gorski, T.; Cadore, E.L.; Pinto, S.S.; da Silva, E.M.; Correa, C.S.; Beltrami, F.G.; Kruel, L.F.M. Use of NSAIDs in triathletes: Prevalence, level of awareness and reasons for use. Br. J. Sports Med. 2011, 45, 85-90. [CrossRef] [PubMed]

19. Warden, S.J. Prophylactic Use of NSAIDs by Athletes: A Risk/Benefit Assessment. Physician Sportsmed. 2010, 38, 132-138. [CrossRef] [PubMed]

20. Clarkson, P.M.; Hubal, M.J. Exercise-induced muscle damage in humans. Am. J. Phys. Med. Rehabil. 2002, 81, S52-S69. [CrossRef] [PubMed]

21. Baxter, R.E.; Moore, J.H. Diagnosis and Treatment of Acute Exertional Rhabdomyolysis. J. Orthop. Sports Phys. Ther. 2003, 33, 104-108. [CrossRef]

22. Patel, D.R.; Gyamfi, R.; Torres, A. Exertional Rhabdomyolysis and Acute Kidney Injury. Physician Sportsmed. 2009, 37, 71-79. [CrossRef] [PubMed]

23. Kent, A.L.; Maxwell, L.E.; Koina, M.E.; Falk, M.C.; Willenborg, D.; Dahlstrom, J.E. Renal Glomeruli and Tubular Injury Following Indomethacin, Ibuprofen, and Gentamicin Exposure in a Neonatal Rat Model. Pediatr. Res. 2007, 62, 307-312. [CrossRef]

24. Nelson, D.A.; Marks, E.S.; Deuster, P.A.; O'Connor, F.G.; Kurina, L.M. Association of Nonsteroidal Anti-inflammatory Drug Prescriptions With Kidney Disease Among Active Young and Middle-aged Adults. JAMA Netw. Open 2019, 2, e187896. [CrossRef] [PubMed]

25. Christopher, S.; Tadlock, B.A.; Veroneau, B.J.; Harnish, C.; Perera, N.K.P.; Knab, A.M.; Vallabhajosula, S.; Bullock, G.S. Epidemiological profile of pain and non-steroid anti-inflammatory drug use in collegiate athletes in the United States. BMC Musculoskelet. Disord. 2020, 21, 561. [CrossRef]

26. Zhang, X.; Donnan, P.T.; Bell, S.; Guthrie, B. Non-steroidal anti-inflammatory drug induced acute kidney injury in the community dwelling general population and people with chronic kidney disease: Systematic review and meta-analysis. BMC Nephrol. 2017, 18, 256. [CrossRef] [PubMed]

27. Xu, D.; Hu, M.-J.; Wang, Y.-Q.; Cui, Y.-L. Antioxidant Activities of Quercetin and Its Complexes for Medicinal Application. Molecules 2019, 24, 1123. [CrossRef]

28. Panche, A.N.; Diwan, A.D.; Chandra, S.R. Flavonoids: An overview. J. Nutr. Sci. 2016, 5, e47. [CrossRef] 
29. Chen, C.; Yang, J.-S.; Lu, C.-C.; Chiu, Y.-J.; Chen, H.-C.; Chung, M.-I.; Wu, Y.-T.; Chen, F.-A. Effect of Quercetin on DexamethasoneInduced C2C12 Skeletal Muscle Cell Injury. Molecules 2020, 25, 3267. [CrossRef]

30. Dallak, M.; Dawood, A.F.; Haidara, M.A.; Kader, D.H.A.; Eid, R.A.; Kamar, S.; Eldeen, A.M.S.; Al-Ani, B. Suppression of glomerular damage and apoptosis and biomarkers of acute kidney injury induced by acetaminophen toxicity using a combination of resveratrol and quercetin. Drug Chem. Toxicol. 2020, 3, 1-7. [CrossRef]

31. Kenan Kinaci, M.; Erkasap, N.; Kucuk, A.; Koken, T.; Tosun, M. Effects of quercetin on apoptosis, NF-kB and NOS gene expression in renal ischemia/reperfusion injury. Exp. Ther. Med. 2012, 3, 249-254. [CrossRef]

32. Yagmurca, M.; Yasar, Z.; Bas, O. Effects of quercetin on kidney injury induced by doxorubicin. Bratisl Lek Listy 2015, 116, 486-489. [CrossRef] [PubMed]

33. Zyurt, H.; Çevik, Ö.; Özgen, Z.; Özden, A.S.; Çadırcı, S.; Elmas, M.A.; Ercan, F.; Gören, M.Z.; Şener, G. Quercetin protects radiation-induced DNA damage and apoptosis in kidney and bladder tissues of rats. Free Radic. Res. 2014, 48, 1247-1255.

34. Inal, M.; Altinişik, M.; Bilgin, M.D. The effect of quercetin on renal ischemia and reperfusion injury in the rat. Cell Biochem. Funct. 2002, 20, 291-296. [CrossRef]

35. Leonard, C.E.; Freeman, C.P.; Newcomb, C.W.; Reese, P.P.; Herlim, M.; Bilker, W.B.; Hennessy, S.; Strom, B.L. Proton pump inhibitors and traditional nonsteroidal anti-inflammatory drugs and the risk of acute interstitial nephritis and acute kidney injury. Pharmacoepidemiol. Drug Saf. 2012, 21, 1155-1172. [CrossRef] [PubMed]

36. Murray, M.D.; Brater, D.C.; Tierney, W.M.; Hui, S.L.; McDonald, C.J. Ibuprofen-associated Renal Impairment in a Large General Internal Medicine Practice. Am. J. Med Sci. 1990, 299, 222-229. [CrossRef]

37. Patel, K.; Diamantidis, C.; Zhan, M.; Hsu, V.D.; Walker, L.D.; Gardner, J.; Weir, M.R.; Fink, J.C. Influence of Creatinine versus Glomerular Filtration Rate on Non-Steroidal Anti-Inflammatory Drug Prescriptions in Chronic Kidney Disease. Am. J. Nephrol. 2012, 36, 19-26. [CrossRef]

38. Silverstein, F.E.; Faich, G.; Goldstein, J.L.; Simon, L.S.; Pincus, T.; Whelton, A.; Makuch, R.; Eisen, G.; Agrawal, N.M.; Stenson, W.F.; et al. Gastrointestinal toxicity with celecoxib vs. nonsteroidal anti-inflammatory drugs for osteoarthritis and rheumatoid arthritis: The CLASS study: A randomized controlled trial. Celecoxib Long-term Arthritis Safety Study. JAMA 2000, 284, $1247-1255$. [CrossRef]

39. Catella-Lawson, F.; McAdam, B.; Morrison, B.W.; Kapoor, S.; Kujubu, D.; Antes, L.; Lasseter, K.C.; Quan, H.; Gertz, B.J.; Fitzgerald, G.A. Effects of specific inhibition of cyclooxygenase-2 on sodium balance, hemodynamics, and vasoactive eicosanoids. J. Pharmacol. Exp. Ther. 1999, 289, 735-741.

40. Whelton, A.; Schulman, G.; Wallemark, C.; Drower, E.J.; Isakson, P.C.; Verburg, K.M.; Geis, G.S. Effects of Celecoxib and Naproxen on Renal Function in the Elderly. Arch. Intern. Med. 2000, 160, 1465-1470. [CrossRef]

41. Kellum, J.A.; Lameire, N.; Aspelin, P.; Barsoum, R.S.; Burdmann, E.A.; Goldstein, S.L.; Herzog, C.A.; Joannidis, M.; Kribben, A.; Levey, A.S. Kidney disease: Improving global outcomes (KDIGO) acute kidney injury work group. KDIGO clinical practice guideline for acute kidney injury. Kidney Int. Suppl. 2012, 2, 138.

42. Dreischulte, T.; Donnan, P.; Grant, A.; Hapca, A.; McCowan, C.; Guthrie, B. Safer Prescribing-A Trial of Education, Informatics, and Financial Incentives. N. Engl. J. Med. 2016, 374, 1053-1064. [CrossRef]

43. Guthrie, B.; Kavanagh, K.; Robertson, C.; Barnett, K.; Treweek, S.; Petrie, D.; Ritchie, L.; Bennie, M. Data feedback and behavioural change intervention to improve primary care prescribing safety (EFIPPS): Multicentre, three arm, cluster randomised controlled trial. BMJ 2016, 354, i4079. [CrossRef]

44. Dreischulte, T.; Morales, D.R.; Bell, S.; Guthrie, B. Combined use of nonsteroidal anti-inflammatory drugs with diuretics and/or renin-angiotensin system inhibitors in the community increases the risk of acute kidney injury. Kidney Int. 2015, 88, 396-403. [CrossRef] [PubMed]

45. Bouck, Z.; Mecredy, G.C.; Ivers, N.M.; Barua, M.; Martin, D.; Austin, P.C.; Tepper, J.; Bhatia, R.S. Frequency and Associations of Prescription Nonsteroidal Anti-inflammatory Drug Use Among Patients With a Musculoskeletal Disorder and Hypertension, Heart Failure, or Chronic Kidney Disease. JAMA Intern. Med. 2018, 178, 1516-1525. [CrossRef]

46. Centers for Disease Control and Prevention. Chronic Kidney Disease in the United States; US Department of Health and Human Services: Atlanta, GA, USA, 2019.

47. Plantinga, L.; Grubbs, V.; Sarkar, U.; Hsu, C.-Y.; Hedgeman, E.; Robinson, B.; Saran, R.; Geiss, L.; Burrows, N.R.; Eberhardt, M.; et al. Nonsteroidal Anti-Inflammatory Drug Use Among Persons With Chronic Kidney Disease in the United States. Ann. Fam. Med. 2011, 9, 423-430. [CrossRef] [PubMed]

48. Abbas, E.E.; AlBawab, I.M.; Safarini, S.K.; Alhassan, R.A.; Khatim, M.S. The Effect of Short Term Use of Indomethacin, a Non-Steroidal Anti-inflammatory Drug, on Peritoneal Dialysis Patients. Saudi J. Kidney Dis. Transplant. 1996, 7, 10-14.

49. McCarthy, J.T.; Torres, V.E.; Romero, J.C.; Wochos, D.N.; Velosa, J.A. Acute intrinsic renal failure induced by indomethacin: Role of prostaglandin synthetase inhibition. Mayo Clin. Proc. 1982, 57, 289-296. [PubMed]

50. Dixit, M.; Doan, T.; Kirschner, R.; Dixit, N. Significant Acute Kidney Injury Due to Non-steroidal Anti-inflammatory Drugs: Inpatient Setting. Pharmaceuticals 2010, 3, 1279-1285. [CrossRef]

51. Ravnskov, U. Glomerular, tubular and interstitial nephritis associated with non-steroidal anti-inflammatory drugs. Evidence of a common mechanism. Br. J. Clin. Pharmacol. 1999, 47, 203-210. [CrossRef] [PubMed]

52. Krishnan, N.; Perazella, M.A. Drug-induced acute interstitial nephritis: Pathology, pathogenesis, and treatment. Iran. J. Kidney Dis. 2015, 9, 3-13. 
53. Zarghi, A.; Arfaei, S. Selective COX-2 Inhibitors: A Review of Their Structure-Activity Relationships. Iran. J. Pharm. Res. 2011, 10, 655-683. [PubMed]

54. Patrignani, P.; Tacconelli, S.; Sciulli, M.G.; Capone, M.L. New insights into COX-2 biology and inhibition. Brain Res. Rev. 2005, 48, 352-359. [CrossRef]

55. Bertolini, A.; Ottani, A.; Sandrini, M. Dual acting anti-inflammatory drugs: A reappraisal. Pharmacol. Res. 2001, 44, 437-450. [CrossRef] [PubMed]

56. Patel, N.S.; Cuzzocrea, S.; Collino, M.; Chaterjee, P.K.; Mazzon, E.; Britti, D.; Yaqoob, M.M.; Thiemermann, C. The role of cycloxygenase-2 in the rodent kidney following ischaemia/reperfusion injury in vivo. Eur. J. Pharmacol. 2007, 562, 148-154. [CrossRef]

57. Harirforoosh, S.; Jamali, F. Renal adverse effects of nonsteroidal anti-inflammatory drugs. Expert Opin. Drug Saf. 2009, 8, 669-681. [CrossRef] [PubMed]

58. Ou, Y.-C.; Yang, C.-R.; Cheng, C.-L.; Li, J.-R.; Raung, S.-L.; Hung, Y.-Y.; Chen, C.-J. Indomethacin causes renal epithelial cell injury involving Mcl-1 down-regulation. Biochem. Biophys. Res. Commun. 2009, 380, 531-536. [CrossRef]

59. Ou, Y.-C.; Yang, C.-R.; Cheng, C.-L.; Raung, S.-L.; Hung, Y.-Y.; Chen, C.-J. Indomethacin induces apoptosis in 786-O renal cell carcinoma cells by activating mitogen-activated protein kinases and AKT. Eur. J. Pharmacol. 2007, 563, 49-60. [CrossRef]

60. Brentnall, M.; Rodriguez-Menocal, L.; De Guevara, R.L.; Cepero, E.; Boise, L.H. Caspase-9, caspase-3 and caspase-7 have distinct roles during intrinsic apoptosis. BMC Cell Biol. 2013, 14, 32. [CrossRef]

61. Li, Z.; Jo, J.; Jia, J.-M.; Lo, S.-C.; Whitcomb, D.; Jiao, S.; Cho, K.; Sheng, M. Caspase-3 Activation via Mitochondria Is Required for Long-Term Depression and AMPA Receptor Internalization. Cell 2010, 141, 859-871. [CrossRef]

62. Hao, C.-M.; Kömhoff, M.; Guan, Y.; Redha, R.; Breyer, M.D. Selective targeting of cyclooxygenase-2 reveals its role in renal medullary interstitial cell survival. Am. J. Physiol. Content 1999, 277, F352-F359. [CrossRef]

63. Danon, A.; Leibson, V.; Assouline, G. Effects of aspirin, indomethacin, flufenamic acid and paracetamol on prostaglandin output from rat stomach and renal papilla in-vitro and ex-vivo. J. Pharm. Pharmacol. 1983, 35, 576-579. [CrossRef]

64. Schmidt, J.; Klingler, F.-M.; Proschak, E.; Steinhilber, D.; Schubert-Zsilavecz, M.; Merk, D. NSAIDs Ibuprofen, Indometacin and Diclofenac do not interact with Farnesoid X Receptor. Sci. Rep. 2015, 5, 14782. [CrossRef]

65. Kavsan, V.M.; Iershov, A.V.; Balynska, O.V. Immortalized cells and one oncogene in malignant transformation: Old insights on new explanation. BMC Cell Biol. 2011, 12, 23. [CrossRef] [PubMed]

66. Shaw, G.; Morse, S.; Ararat, M.; Graham, F.L. Preferential transformation of human neuronal cells by human adenoviruses and the origin of HEK 293 cells. FASEB J. 2002, 16, 869-871. [CrossRef] [PubMed]

67. Lin, Y.-C.; Boone, M.; Meuris, L.; Lemmens, I.; Van Roy, N.; Soete, A.; Reumers, J.; Moisse, M.; Plaisance, S.; Drmanac, R.; et al. Genome dynamics of the human embryonic kidney 293 lineage in response to cell biology manipulations. Nat. Commun. 2014, 5, 4767. [CrossRef] [PubMed]

68. Wang, C.; Youle, R.J. The Role of Mitochondria in Apoptosis. Annu. Rev. Genet. 2009, 43, 95-118. [CrossRef]

69. Estaquier, J.; Vallette, F.; Vayssiere, J.L.; Mignotte, B. The mitochondrial pathways of apoptosis. Adv. Exp. Med. Biol. 2012, 942, 157-183.

70. Lodi, A.; Tiziani, S.; Khanim, F.L.; Drayson, M.; Günther, U.L.; Bunce, C.M.; Viant, M.R. Hypoxia Triggers Major Metabolic Changes in AML Cells without Altering Indomethacin-Induced TCA Cycle Deregulation. ACS Chem. Biol. 2011, 6, 169-175. [CrossRef]

71. Carrasco-Pozo, C.; Pastene, E.; Vergara, C.; Zapata, M.; Sandoval, C.; Gotteland, M. Stimulation of cytosolic and mitochondrial calcium mobilization by indomethacin in Caco-2 cells: Modulation by the polyphenols quercetin, resveratrol and rutin. Biochim. Biophys. Acta BBA Gen. Subj. 2012, 1820, 2052-2061. [CrossRef]

72. Tsutsumi, S.; Gotoh, T.; Tomisato, W.; Mima, S.; Hoshino, T.; Hwang, H.-J.; Takenaka, H.; Tsuchiya, T.; Mori, M.; Mizushima, T. Endoplasmic reticulum stress response is involved in nonsteroidal anti-inflammatory drug-induced apoptosis. Cell Death Differ. 2004, 11, 1009-1016. [CrossRef]

73. Qi, X.; Cai, Y.; Gong, L.; Liu, L.; Chen, F.; Xiao, Y.; Wu, X.; Li, Y.; Xue, X.; Ren, J. Role of mitochondrial permeability transition in human renal tubular epithelial cell death induced by aristolochic acid. Toxicol. Appl. Pharmacol. 2007, 222, 105-110. [CrossRef]

74. Wang, Y.; Quan, F.; Cao, Q.; Lin, Y.; Yue, C.; Bi, R.; Cui, X.; Yang, H.; Yang, Y.; Birnbaumer, L.; et al. Quercetin alleviates acute kidney injury by inhibiting ferroptosis. J. Adv. Res. 2021, 28, 231-243. [CrossRef]

75. Lu, H.; Wu, L.; Liu, L.; Ruan, Q.; Zhang, X.; Hong, W.; Wu, S.; Jin, G.; Bai, Y. Quercetin ameliorates kidney injury and fibrosis by modulating M1/M2 macrophage polarization. Biochem. Pharmacol. 2018, 154, 203-212. [CrossRef]

76. Zhang, M.; Swarts, S.G.; Yin, L.; Liu, C.; Tian, Y.; Cao, Y.; Swarts, M.; Yang, S.; Zhang, S.B.; Zhang, K.; et al. Antioxidant Properties of Quercetin. Adv. Exp. Med. Biol. 2011, 701, 283-289. [CrossRef] [PubMed]

77. Manvelian, G.; Daniels, S.; Altman, R. A Phase I Study Evaluating the Pharmacokinetic Profile of a Novel, Proprietary, Nanoformulated, Lower-Dose Oral Indomethacin. Postgrad. Med. 2012, 124, 197-205. [CrossRef] [PubMed]

78. Pountos, I.; Georgouli, T.; Calori, G.M.; Giannoudis, P.V. Do Nonsteroidal Anti-Inflammatory Drugs Affect Bone Healing? A Critical Analysis. Sci. World J. 2012, 2012, 606404. [CrossRef] [PubMed]

79. Shu-Ping, L.I.; Guo-Fu, H.U. Mechanism and Function of Angiogenin in Apoptosis Regulation. Chin. J. Biochem. Mol. Biol. 2015, 31, 1258-1260. [CrossRef]

80. Martinvalet, D. ROS signaling during granzyme B-mediated apoptosis. Mol. Cell. Oncol. 2015, 2, e992639. [CrossRef] 
81. Tian, B.; Yang, Q.; Mao, Z. Phosphorylation of ATM by Cdk5 mediates DNA damage signalling and regulates neuronal death. Nat. Cell Biol. 2009, 11, 211-218. [CrossRef]

82. Kozlov, S.V.; Graham, M.E.; Jakob, B.; Tobias, F.; Kijas, A.W.; Tanuji, M.; Chen, P.; Robinson, P.J.; Taucher-Scholz, G.; Suzuki, K.; et al. Autophosphorylation and ATM activation: Additional sites add to the complexity. J. Biol. Chem. 2011, 286, 9107-9119. [CrossRef] [PubMed]

83. Wang, W.; Li, J.; Tan, J.; Wang, M.; Yang, J.; Zhang, Z.-M.; Li, C.; Basnakian, A.G.; Tang, H.-W.; Perrimon, N.; et al. Endonuclease G promotes autophagy by suppressing mTOR signaling and activating the DNA damage response. Nat. Commun. 2021, 12, 476. [CrossRef]

84. Yan, C.; Xin-Ming, Q.; Li-Kun, G.; Lin-Lin, L.; Fang-Ping, C.; Ying, X.; Xiong-Fei, W.; Xiang-Hong, L.; Jin, R. Tetrandrine-induced apoptosis in rat primary hepatocytes is initiated from mitochondria: Caspases and Endonuclease G (Endo G) pathway. Toxicology 2006, 218, 1-12. [CrossRef]

85. Wiehe, R.S.; Gole, B.; Chatre, L.; Walther, P.; Calzia, E.; Ricchetti, M.; Wiesmüller, L. Endonuclease G promotes mitochondrial genome cleavage and replication. Oncotarget 2018, 9, 18309-18326. [CrossRef]

86. Rodríguez-Vargas, J.M.; Magaña, M.J.R.; Ruiz, M.R.; Majuelos-Melguizo, J.; Peralta-Leal, A.; Rodriguez, J.M.; Muñoz-Gámez, J.A.; De Almodóvar, M.R.; Siles, E.; Rivas, A.L.; et al. ROS-induced DNA damage and PARP-1 are required for optimal induction of starvation-induced autophagy. Cell Res. 2012, 22, 1181-1198. [CrossRef] [PubMed]

87. Sevrioukova, I.F. Apoptosis-Inducing Factor: Structure, Function, and Redox Regulation. Antioxid. Redox Sig. 2011, 14, 2545-2579. [CrossRef] [PubMed]

88. Davis, J.S.; Lee, H.Y.; Kim, J.; Advani, S.M.; Peng, H.-L.; Banfield, E.; Hawk, E.T.; Chang, S.; Wood, L. Use of non-steroidal anti-inflammatory drugs in US adults: Changes over time and by demographic. Open Heart 2017, 4, e000550. [CrossRef]

89. Zhou, X.; Zuo, S.; Xin, W. miR-27b overexpression improves mitochondrial function in a Sirt1-dependent manner. J. Physiol. Biochem. 2015, 71, 753-762. [CrossRef] [PubMed]

90. Boonyong, C.; Vardhanabhuti, N.; Jianmongkol, S. Natural polyphenols prevent indomethacin-induced and diclofenac-induced Caco-2 cell death by reducing endoplasmic reticulum stress regardless of their direct reactive oxygen species scavenging capacity. J. Pharm. Pharmacol. 2020, 72, 583-591. [CrossRef]

91. Diniz, L.R.L.; Souza, M.T.D.S.; Duarte, A.B.S.; de Sousa, D.P. Mechanistic Aspects and Therapeutic Potential of Quercetin against COVID-19-Associated Acute Kidney Injury. Molecules 2020, 25, 5772. [CrossRef] [PubMed]

92. Tan, R.Z.; Wang, C.; Deng, C.; Zhong, X.; Yan, Y.; Luo, Y.; Lan, H.Y.; He, T.; Wang, L. Quercetin protects against cisplatin-induced acute kidney injury by inhibiting Mincle/Syk/NF-кB signaling maintained macrophage inflammation. Phytother. Res. 2020, 34, 139-152. [CrossRef]

93. Alshanwani, A.R.; Shaheen, S.; Faddah, L.M.; Alhusaini, A.M.; Ali, H.M.; Hasan, I.; Hagar, H.; Ahmed, R.; Alharbi, F.M.B.; Al Harthii, A. Manipulation of Quercetin and Melatonin in the Down-Regulation of HIF-1 $\alpha$, HSP-70 and VEGF Pathways in Rat's Kidneys Induced by Hypoxic Stress. Dose Response 2020, 18, 1559325820949797. [CrossRef]

94. Wang, C.; Pan, Y.; Zhang, Q.-Y.; Wang, F.-M.; Kong, L.-D. Quercetin and Allopurinol Ameliorate Kidney Injury in STZ-Treated Rats with Regulation of Renal NLRP3 Inflammasome Activation and Lipid Accumulation. PLoS ONE 2012, 7, e38285. [CrossRef]

95. Ha, H.A.; Chiang, J.H.; Tsai, F.J.; Bau, D.T.; Juan, Y.N.; Lo, Y.H.; Hour, M.J.; Yang, J.S. Novel quinazolinone MJ33 induces AKT/mTORmediated autophagyassociated apoptosis in 5FUresistant colorectal cancer cells. Oncol. Rep. 2021, 45, 680-692. [CrossRef]

96. Lee, C.-F.; Yang, J.-S.; Tsai, F.-J.; Chiang, N.-N.; Lu, C.-C.; Huang, Y.-S.; Chen, C.; Chen, F.-A. Kaempferol induces ATM/p53mediated death receptor and mitochondrial apoptosis in human umbilical vein endothelial cells. Int. J. Oncol. 2016, 48, 2007-2014. [CrossRef] [PubMed]

97. Lin, C.C.; Chen, K.B.; Tsai, C.H.; Tsai, F.J.; Huang, C.Y.; Tang, C.H.; Yang, J.S.; Hsu, Y.M.; Peng, S.F.; Chung, J.G. Casticin inhibits human prostate cancer DU 145 cell migration and invasion via Ras/Akt/NF-kappaB signaling pathways. J. Food. Biochem. 2019, 43, e12902. [CrossRef] [PubMed]

98. Lee, C.-F.; Chiang, N.-N.; Lu, Y.-H.; Huang, Y.-S.; Yang, J.-S.; Tsai, S.-C.; Lu, C.-C.; Chen, F.-A. Benzyl isothiocyanate (BITC) triggers mitochondria-mediated apoptotic machinery in human cisplatin-resistant oral cancer CAR cells. BioMedicine 2018, 8, 15. [CrossRef] [PubMed]

99. Wu, K.-M.; Hsu, Y.-M.; Ying, M.-C.; Tsai, F.-J.; Tsai, C.-H.; Chung, J.-G.; Yang, J.-S.; Tang, C.-H.; Cheng, L.-Y.; Su, P.-H.; et al. High-density lipoprotein ameliorates palmitic acid-induced lipotoxicity and oxidative dysfunction in H9c2 cardiomyoblast cells via ROS suppression. Nutr. Metab. 2019, 16, 36. [CrossRef] [PubMed]

100. Lee, M.-R.; Lin, C.; Lu, C.-C.; Kuo, S.-C.; Tsao, J.-W.; Juan, Y.-N.; Chiu, H.-Y.; Lee, F.-Y.; Yang, J.-S.; Tsai, F.-J. YC-1 induces G0/G1phase arrest and mitochondria-dependent apoptosis in cisplatin-resistant human oral cancer CAR cells. BioMedicine 2017, 7, 12. [CrossRef]

101. Chung, J.-G.; Yang, J.-S.; Huang, L.-J.; Lee, F.-Y.; Teng, C.-M.; Tsai, S.-C.; Lin, K.-L.; Wang, S.-F.; Kuo, S.-C. Proteomic approach to studying the cytotoxicity of YC-1 on U937 leukemia cells and antileukemia activity in orthotopic model of leukemia mice. Proteomics 2007, 7, 3305-3317. [CrossRef]

102. Ho, Y.-T.; Lu, C.-C.; Yang, J.-S.; Chiang, J.-H.; Li, T.-C.; Ip, S.-W.; Hsia, T.-C.; Liao, C.-L.; Lin, J.-G.; Wood, W.G.; et al. Berberine induced apoptosis via promoting the expression of caspase-8, -9 and -3 , apoptosis-inducing factor and endonuclease G in SCC-4 human tongue squamous carcinoma cancer cells. Antican. Res. 2009, 29, 4063-4070. 